\title{
Editorial: Mental Health in International Migration
}

Éditorial : La santé mentale en migrations internationales

Editorial: La salud mental en las migraciones internacionales

\section{Véronique Petit and Simeng Wang}

Translator. Katherine Booth and Alexandra Poméon O'Neill

\section{(2) OpenEdition}

Journals

\section{Electronic version}

URL: https://journals.openedition.org/remi/14302

DOI: 10.4000/remi.14302

ISSN: $1777-5418$

This article is a translation of:

Éditorial : La santé mentale en migrations internationales - URL : https://journals.openedition.org/ remi/10489 [fr]

\section{Publisher}

Université de Poitiers

Printed version

Date of publication: 1 October 2018

ISBN: 979-10-90426-62-7

ISSN: 0765-0752

\section{Electronic reference}

Véronique Petit and Simeng Wang, "Editorial: Mental Health in International Migration", Revue européenne des migrations internationales [Online], vol. 34 - n² et $3 \mid 2018$, Online since 17 September 2020, connection on 14 April 2022. URL: http://journals.openedition.org/remi/14302 ; DOI: https:// doi.org/10.4000/remi. 14302

This text was automatically generated on 14 April 2022.

(c) Université de Poitiers 


\title{
Editorial: Mental Health in International Migration
}

\author{
Éditorial : La santé mentale en migrations internationales \\ Editorial: La salud mental en las migraciones internacionales
}

Véronique Petit and Simeng Wang

Translation : Katherine Booth and Alexandra Poméon O'Neill

1 The Revue Européenne des Migrations Internationales has never published a dossier on mental health in migration. We considered it necessary to fill this gap without claiming to deal with all the questions that could have been included within this broad topic. There are several reasons for this choice. The first is based on a wish to react to certain political and semantic excesses in a number of European societies characterised by a socio-political context marked by the "migrant crisis". A special issue devoted to mental health in migration allows us to present a scholarly discourse based on empirical knowledge, whether clinical or from the field of social sciences, in response to certain political injunctions and populist tendencies against "sick migrants" which are becoming increasingly widespread in the media and political arena. By focusing on the interactions between international migration and mental health, it becomes possible, on the basis of precise observations, to highlight the reality and complexity of the social conditions of migration, to examine the health practices of migrants as an indicator of the "reception" reserved for them, the links they maintain with their families and their own capacity to act during their therapeutic journey. Behind this attention to the facts and the caution that the analyses require, the aim is to denounce shortcuts that carry untruths, all the more dangerous as they are employed by people with power and responsibilities. As an example, the former Minister of the Interior, Gérard Collomb, who following the attacks in Spain in 2017 declared that he wanted to put in place "mobilisation of all psychiatric hospitals and psychiatrists in private practice in order to attempt to counter this individual terrorist threat", "these protocols" should be put in place "at a time when a certain number of people have delusions about Islamic radicalisation" ${ }^{1}$. These comments were strongly criticised by the medical profession, which had no hesitation in deconstructing and rejecting them. 
Indeed, the speech of the former Minister of the Interior is based on false and dangerous ideas that more or less implicitly associate mental illness, religion and terrorism. Insidiously, this discourse, by associating religion and illness with state security, calls into question the right of people from a migrant background to legitimately experience their beliefs and illnesses. It is an extension of the generalised regime of suspicion towards migrants and indeed questions the place that we reserve for foreigners in our societies and our capacity to hear their voices and their multiple sufferings (see the news column by Marie-Caroline Saglio-Yatzimirsky and Laure Wolmark).

\section{The mental health of migrants: what particularities?}

2 Studies on the mental health of international migrants are not unrelated, in one way or another, to ethno-psychiatry, which emerged during the $20^{\text {th }}$ century from a marriage between ethnology and psychiatry. According to Georges Devereux, founding father of the ethno-psychiatrist, it "must be a 'metacultural' approach, i.e. one which is not limited to the ethnography of a society, but which transcends differences through a general understanding of Culture, in the sense of a general theory of culture... There is a theoretical framework that can make the distinction between normal and pathological relevant, whatever the culture," (Rechtman, 2018a: 93-94). Since then, research has focused on the introduction and dissemination of psychiatry within colonial empires as a medical discipline and an instrument of social regulation (Collignon et al., 1977; Collignon, 1999), the confrontation between this biomedical knowledge and local representations of disease (Beneduce, 1997; Ortigues and Ortigues, 1966; Collomb, 1967), and the complex legacy of psychiatric institutions (Storper-Perez, 1974; Keller, 2007; Kilroy-Marac, 2009). Some research has also sought to show the consequences of socio-economic and political changes (e.g. urbanisation, industrialisation, proletarisation, impoverishment) on living conditions and how they may affect the mental health of individuals (Comaroff and Comaroff, 1987; Thomas and Znaniecki, 1998). In many studies, it is observed that the urban world is associated with spatial mobility (internal migration, rural exodus, international migration), individuation and the acceleration of time. Migrants must then adapt to this new social environment, which is described as pathogenic because of the novel aspects and violence that individuals have to deal with. The decolonisation of the 1970s shifted the question of otherness in psychiatry and the role of culture in the expression of illnesses, importing it from exotic lands (Fassin, 1999 and 2000a; Collignon, 1999 and 2006) to the heart of Western societies. From this date, ethno-psychiatry, which until then had remained highly dependent on colonial territories, became an urban practice with regard to immigrant and refugee populations (Rechtman, 2018a: 97).

3 Indeed, the psyche is revealed through the mediation of language, gestures, emotions and attitudes. The expression of psychological suffering varies considerably from one culture to another. When dealing with a migrant subject, there can be a greater otherness in therapeutic relationships. For this reason, ethno-psychiatry, transcultural psychiatry, psychotherapy, psychoanalysis have drawn on anthropological knowledge to approach the psyche through cultural differences. However, being sensitive to "cultural" variability does not mean reducing the interpretation of the psyche to culturalist explanations. Breaking out of a dichotomy between the West and the rest of 
the world, contemporary studies on mental health and mental suffering in the context of international migration are encouraged to consider all spheres of the contemporary world. Since "from one historical period to another, but also from one social group to another, we do not express our innermost thoughts and feelings with the same words, we do not use the same expressions, we do not use the same gestures" (Rechtman, 2018b: 402). Studying mental health in international migration thus reveals how an individual carries out the effort of "self-adjustment" (Ehrenberg, 2000) in contexts of spatial and social mobility; and how migrants position themselves in the face of social norms designating and attributing the status of "sick" and "crazy", both in their country of origin and in the host society (Rechtman, 2000).

\section{The fertility of the prism of mental health for migration studies: micro, meso and macro analytical scales}

\section{Subjectivity and private life of migrants}

Mental health and mental suffering constitute above all a valuable prism for the study of an individual's personal life. Through narratives, discourses and words, as mediators of the psyche and revealing of subjectivity (Ochs and Capps, 1996; Ochs and Sterponi, 2003), researchers examine how patients and their entourage draw on local interpretations - representations, rituals, the imaginary - to give meaning to migratory journeys marked by illness (Sylla and Mbaye, 1990-1991) and to question the migratory project initially conceived. Working on the mental health of people involved in a migratory experience means taking into consideration the voices of migrants who are suffering and questioning the social conditions of their narratives, what is said and what is unsaid. How do they assume their role as "sick" or as people designated as "crazy"? Although some migrants are subjected to extreme violence during their journey or to insecure living conditions, they remain actors in their mobility, and in their social trajectory, in which the migratory experience and their experiences of suffering and illness play a part. Undertaking a therapeutic journey also means asserting the pre-eminence of life, regaining lost or violated dignity, and asking oneself existentially about the meaning of one's migratory trajectory and the multiple experiences that are inextricably linked to it. It is to become "another self for oneself" (Ricœur, 1987), since illness as an individual and social fact obliges us to question and put into perspective our personal history and our own trajectory.

\section{Family configurations and intergenerational relations}

5 Considering the mental health of migrants inevitably necessitates taking into account the patient's family configuration as a whole, since a care itinerary cannot be separated from a social trajectory that links the country of origin and the host country (Sayad, 1999; Wang, 2017; Muel-Dreyfus, 2018; Pryor et al., 2019). Often carrying multiple expectations (financial, social, material, emotional, symbolic, etc.) from their families and relatives, international migrants can find themselves in a state of debt, both economic and moral (Wang, 2014). The meaning given to illness and the strategies of concealment in the face of illness, shame and the impact that mental disorders can have on the realisation of the migration project significantly modify family dynamics 
and the links between the migrant and his/her family environment (Ly et al., 2014). For example, in the case of Chinese families in Paris in which a child has psychological difficulties or mental disorders, their care and therapeutic itinerary are determined by the migratory trajectories of the entire family, both in the decision to register the child at a Maison départementale des personnes handicapées (Departmental Home for Disabled Persons - MDPH) (Wang, 2013b) and in the process of regularisation for medical reasons (Wang, 2016b). In this respect, the prism of mental health and psychological suffering proves to be productive since it reveals the family and intergenerational relationships in which the migrant lives, and also informs us about the transformation of these family relationships during the migratory trajectory, from pre-migration to post-immigration.

\section{Therapeutic relationships and modes of care}

Studying mental health in a context of international migration enables, on another analytical scale, discussion of the caregiver/care-receiver relationships and the modes of care - health, social and legal - for migrants. Access to (mental) health care for migrants constitutes a dual prism: on the one hand, it reveals the care offer available, its quality and means of access; and on the other hand, it provides an insight into migration policies and conditions of integration in countries of immigration. Existing studies deal with clinical approaches (Rechtman and Welsh, 1993); the place of culture in health care, whether in the countries of departure or arrival of migrants (Nathan, 2000; Fassin, 1999 and 2000a; Wang, 2013b); the practices and challenges of interpreting and mediation (Wang, 2013a; Béal and Chambon, 2015; Blommaert, 2001; Belkacem, 2015; Wang, 2016c). These studies have in common that they question public policies at the intersection of migration and health, the organisation of the health care system, and more broadly the reception of migrants in the countries of settlement, and the phenomena of return to the countries of origin for care and treatment. Observing mental health in migration also involves looking at the interactions between several types of actors involved in the care of migrants. People living with a mental disorder and psychological problem may themselves initiate a therapeutic quest, or be offered specific care in a specific social configuration: with the status of "refugee" or "unaccompanied minor", being received in a camp, having engaged in misconduct in the public space, falling behind in school, etc.

\section{Medical pluralism and circulation in health}

7 Finally, focusing on mental health in a migratory context is also a way of studying the links between different medical systems and the transnational circulation of knowledge and care practices. The migratory journey engenders sometimes complex therapeutic pathways by widening the range of possible care in contexts of therapeutic pluralism on both sides. The migrant as an actor of globalisation - care-receivers and caregivers is a prime carrier of medical and paramedical standards and therapeutic practices, and of non-material transfers in particular in the fields of training of health professionals. Indeed, not all migrants are satisfied with biomedical care; recourse to so-called "alternative" mental health care and international care practices are frequently observed among international migrants (Crenn et al., 2010; Wang, 2012). The mobilisation of these multiple resources and their uses must be questioned with regard 
to processes of (re)socialisation, social differentiation, and social trajectories and mobilities.

\section{A theme that has thus far received little attention from REMI}

While the issue of the links between mental health and migratory experiences appears relatively early in the history of social sciences, notably studied by the Chicago School (Faris and Dunham, 1939), it has rarely been treated as a central subject in the Revue Européenne des Migrations Internationales. Only one article explicitly refers to this issue in its title (Devarenne-Megas, 2003). Even the issue of health, which is less specific than that of mental health, remains relatively little addressed. Between 1980 and 2019, REMI published only one dossier directly devoted to "Health Experiences in Migration", coordinated by Cognet, Hoyez and Poiret (2012). The coordinators and contributors focused on analysing the inequalities and discrimination suffered by migrants compared to individuals born French in France, thus supplementing the first overview by Berchet and Jusot (2012) and deepening the perspective initiated by Fassin (2000b). This issue examines access to care for different pathologies (cancer, HIV, maternal health, palliative care) during the migratory trajectory, the effects of living conditions (housing, employment) on health and the interactions between access to care and various administrative arrangements.

REMI has also published about twenty articles dealing with the issue of health in migration through various themes: therapeutic pathways, health practices according to administrative status, gender and ethnic origin (Aumond, 2017; Alpes, 2017), the effects of discrimination, inequalities between migrants and people belonging to the majority group, the place of health in the protection granted to refugees (Gómez Martín, 2016), the mobility of health professionals (Blain et al., 2014) and their views on the migratory or colonial situation (Moussy, 2015), health as a prism through which to view integration, the contribution of migrants considered as "development actors" in the healthcare systems of the countries of departure (Ndione and Lombard, 2004). In the absence of a significant number of articles, references to "health" and "mental health" appear more frequently, in the analysis of interactions linking migrants' profiles to specific social, political and administrative contexts that generate multiple forms of vulnerability and violence ${ }^{2}$. This reflects the way in which the multiple dimensions of health are intertwined in the migratory trajectories and experiences that mark both bodies and minds.

\section{Presentations of contributions to this issue}

10 The articles that make up this dossier are from various disciplines: anthropology, sociology, demography, psychology, medicine, geography. This plurality produces specific approaches and methodologies as well as varied fields of investigation. The plurality of migrant profiles and situations described in this dossier makes it possible to go beyond the issue of post-traumatic stress disorder (PTSD), strongly associated with mental health in migration, to show the diversity of psychological suffering, which can affect everyone with a migration background. 
11 In this dossier on mental health in international migration, the mental health of migrants is captured at different points in the migration trajectory. Three articles look at the early stages following arrival in the European Union in France and Greece, exiles recount the tragedies they have endured, the ordeals they are going through (waiting, suspicion, the status of survivor, anxiety about being repatriated) and the physical and psychological traumas which have lastingly scarred them. Through the case of refugee victims of torture who have arrived in Greece, Gail Womersley and Laure Kloetzer analyse the way in which they express their suffering and mental disorders. They are particularly interested in the way in which PTSD is formulated, constructed and diagnosed through migrants' accounts, portrayals and the practices of cultural mediators and health professionals around trauma. They underline the fundamental importance of the cultural mediator in order to grasp the particularities of migratory experiences by translating between worlds, rather than between languages, in the context of the influx of refugees into the European Union. The issue of interpreting also runs through the article by Anaiik Pian, Anne-Cécile Hoyez and Simona Tersigni about mental healthcare provision for migrants in two specific contexts. The analysis of local systems (in Rennes and Strasbourg) for dealing with the psychological suffering of migrants, the positions and expectations of the actors (health professionals, associations, interpreters, migrants), and the construction of a triangular relationship between migrants, interpreters and healthcare workers reveal the interconnection between therapeutic and political issues at the local level. Differentiated approaches to interpreting raise questions about the professionalisation of interpreting - its role, the "right" distance to be maintained from migrants and health workers - and the therapeutic and social monitoring of migrants. What significance do these actors give to cultural explanations within the therapeutic relationship? Finally, the text by Lou Einhorn, Maud Rivière, Marielle Chappuis, Marie Chevelle and Sophie Laurence describes the mental health and psychological support response put in place by an NGO in what they describe as a context of "crisis for exiles". In addition to the theoretical framework of the therapeutic support system proposed, this article looks at the tragic effects of the "reception" conditions for migrants in the Calais region. The violence they suffer is neither that which forced them to flee nor that of those who exploited them during their journey, but the structural violence in the country of arrival. The health workers need to re-establish the possibility of building relationships of trust in an environment that is hardly conducive to therapeutic support, since these slumcamps are marked by stress, insecurity, destitution and uncertainty about the future.

Other articles focus on mental health of migrants who have been settled for years in the country of arrival through the issue of the link that migrants have with their families in the country of departure. While research on remittances has shown how migrants' participation in their families' economies at home has a direct impact on the well-being of their families, there are fewer studies showing that migrants in exile also rely on emotional and psychological resources in their daily struggles to regularise their situation, obtain employment or housing, and achieve improvements in their circumstances. Julie Pannetier, writing for the Parcours group, demonstrates the positive and statistically significant effect of family support based on a demographic survey. This result - which may seem obvious or banal to those with clinical experience - is corroborated using a quantitative demographic approach. 
13 The articles dealing with the contexts of migrants' departures or, in the case of migrants' descendants, with their countries of origin, make it possible to shift the focus to the history and conditions of practice of psychiatry in postcolonial areas and in cultures marked by a high level of therapeutic pluralism (Melchior et al., 2012; Wang, 2016a). There, as here, the aim is map out the way in which the care offer is structured at multiple levels (local, regional, national, transnational), the types of care offered to respond (or fail to respond) to the suffering of migrants and their descendants, how it is linked to a migration policy or a health policy. The issue of access to health care makes it possible to gain an understanding of the living conditions of migrants and the resources available to them, including to express their existential suffering, which is sometimes passed on as an unspeakable legacy. These various dimensions make it possible to set out the context in which their discourse is produced and to reinsert it into a story in motion. Several contributions to this issue highlight the dynamics and movements linking the country of origin and the country of arrival. From a psychological and epidemiological perspective, Kossigan Kokou-Kpolou, Daniel Mbassa Menick, Charlemagne Simplice Moukouta and Élodie Gaëlle Ngameni assessed the effects of mourning a loved one on West African migrants in Europe according to their status and the possibilities of returning to perform certain rituals. François Sicot and slimane Touhami, meanwhile, follow in the footsteps of North African migrants and their descendants along their therapeutic journeys on both sides of the Mediterranean: how do they experience mental illness in a migratory context? What answers do they bring to psychological suffering according to their medical and paramedical knowledge? Which actors will they turn to for medical and/or religious help? Finally, the period of migrants' return to their country of origin is discussed in relation to Senegalese migrants in the article by Véronique Petit. This contribution further explores the perspective raised above, by considering family solidarity when illness undermines the migration project, viewed as a project which is the object of collective investment that is constantly being renewed. The article shows that whatever the causes of return, the migratory experience modifies the migrant's social position and radically changes his or her relationship with others, since the status of migrants remains linked to their success and their redistribution capacity. In the contributions by Julie Pannetier and Véronique Petit, the traditional perspective is reversed, as it is no longer a question of showing how migrants support their parents at home through social or financial transfers, but of understanding how they themselves are profoundly affected by these transnational emotional relationships and the family dynamics of which they are a part. Migrants are also dependent on their families, should it be necessary to underline this form of moral economy.

\section{Shifting the focus: transnational health practices, non- postcolonial immigration and private sector care use}

The articles in this dossier are mainly focused on newcomers, except for the article by François Sicot and Slimane Touhami, which highlights transnational mental health practices among descendants of migrants of North African origin. They show how therapeutic pathways and the way diseases are represented are marked by the transmission of knowledge and practices that complement the biomedical offer in France. These processes of transmission intersect with those of social mobility, calling 
into question proximity and mechanisms of appropriation of psychiatry, psychology and medical and paramedical knowledge in general (psychotherapy, psychoanalysis, so-called "alternative" medicines, religious therapies, etc.). In addition to the migration of different categories of therapists and the movement of people suffering from illnesses, there is also the movement of healthcare products, therapeutic practices and medical and paramedical knowledge. The dissemination of psychiatry, like that of the concept of "mental health", should be further put in its historical context in order to take account of the situations in countries that either are not in a postcolonial situation or do not have a psychiatric care system inherited from colonisation. As can be seen in the case of France, not all components of the colonial empire benefited from an equal investment in the establishment of psychiatric structures (Collignon, 2006). Furthermore, among immigrant populations in France without a postcolonial dimension, as in the case of Chinese immigration, the sociological factors identified over and above the specificities linked to each historical, ethnic and national context of emigration-immigration - have more broadly brought sociological insights into crosscutting issues in migration studies: intergenerational relations, social mobility, therapeutic relations with an intercultural dimension, transnational circulation in health care, and the reception of migrants in France (Wang, 2018).

Although private sector care use is hardly addressed in this dossier, it is important to deconstruct some of the entrenched images attributed to migrants: "poor", "low-skilled or unskilled", "strategic users of public sector care", in order to refine work on social differentiation in the analysis of migrants' care use. In the area of social science research in France, the mental health of certain categories of international migrants and their recourse to care is more widely studied: asylum seekers and refugees (d'Halluin, 2009; Pestre, 2010; Halima et al., 2012; Saglio-Yatzimirsky, 2015 and 2018), migrants in an irregular situation (Wang, 2016b) or those living in situations of extreme fragility (Chambon et al., 2013; Roze et al., 2016). Meanwhile the mental suffering of skilled migrants (Wang, 2015 and 2017), and more broadly of those from the middle and upper classes, and their use of mental health care, are rarely addressed, especially when they are treated in the private psychiatric sector. It would thus seem a heuristic approach to deepen our knowledge on the links between the diversity of categories of international migrants and their therapeutic mental health itinerary; as well as on the social differentiation of recourse to care among international migrants, through the diversity of social relations of race, sex, gender, class, ethnic origin, regional origin, age and generation.

Finally, in terms of research perspectives, independently of research on international migration, mental health is experiencing a revival of interest at the international level for two main reasons. First of all, in the context of the ongoing epidemiological transition, attention is increasingly focused on non-communicable diseases and chronic diseases that require medium- or long-term monitoring. Epidemiological research highlights the discrepancy between the high burden of mental disorders, which is increasingly being measured (Viggo et al., 2016; Charlson et al., 2014; Patel et al., 2018), and the resources devoted to their treatment. This is a dramatic observation for developing countries, particularly in Africa, where the World Health Organization (WHO) estimates that developing countries spend less than $1 \%$ of their health budgets on mental health (Addo et al., 2018; Bloom et al., 2011), that between $75 \%$ and $85 \%$ of individuals with severe mental disorders receive no care at all, and that few countries 
have mental health programmes or policies in place. The area of mental health at the international level is also evolving as a result of the environmental issue and its effects on migration. Indeed, the demographic projections linked to environmental displacement and migration, notwithstanding wide variations in terms of the estimated numbers coming under the category of "environmental refugees" and in the very definition of this category, suggest that this issue will become increasingly important in future migration studies. According to the United Nations High Commissioner for Refugees, 250 million people will be forced to move around the world by 2050; other methodologies and estimates lead to even higher figures. All of these environmental, economic, political, health and legal contexts together give rise to international mobility, which sometimes imposes itself on individuals and shapes their psyche and therapeutic practices. The psychological situation of migrants who are displaced, repatriated, returned or in a fragile transit situation, in the countries of departure and arrival, therefore warrants further research in the era of globalisation.

\section{BIBLIOGRAPHY}

Addo Rebecca, Agyemang Samuel A., Tozan Yesim and Nonvignon Justice (2018) Economic burden of caregiving for persons with severe mental illness in sub-Saharan Africa: A systematic review, PLOS ONE, 13 (8), [online]. URL: https://www.ncbi.nlm.nih.gov/pmc/articles/PMC6084810/

Alpes Maybritt Jill (2017) Les dynamiques sociologiques entre contrôle des migrations et protection sociale : femmes migrantes sans papiers en quête d'hébergement à Paris, Revue Européenne des Migrations Internationales, 33 (4), pp. 135-157.

Aumond Florian (2017) Quand l'exceptionnel dure et le provisoire se normalise : les Centres d'Accueil et d'Orientation pour mineurs non accompagnés (CAOMI), Revue Européenne des Migrations Internationales, 33 (1), pp. 157-163.

Béal Arnaud et Chambon Nicolas (2015) Le recours à l'interprète en santé mentale : enjeux et problèmes, Rhizome, 55 (1), pp. 9-19.

Belkacem Lila (2015) Quand la clinique fait l'ethnique ? Logiques performatives dans la médiation interculturelle pour familles migrantes, Genèses, 98, pp. 47-68.

Beneduce Roberto (1997) Aliénation mentale et altérité du sujet colonial : de quelques difficultés de l'émergence d'une relation thérapeutique basée sur le dialogue en Afrique, in Roberto Beneduce, Saperi, linguaggi e tecniche nei sistemi di cura tradizionali, Torino, L'Harmattan Italia, pp. 71-88.

Berchet Caroline et Jusot Florence (2012) État de santé et recours aux soins des immigrés : une synthèse des travaux français, Questions d'économie de la santé, 172, pp. 1-8.

Blain Marie-Jeanne, Fortin Sylvie et Alvarez Fernando (2014) Être médecin et immigrant au Québec : une identité professionnelle malmenée, Revue Européenne des Migrations Internationales, 30 (3), pp. 139-162.

Blommaert Jan (2001) Context is/as Critique, Critique of anthropology, 21, pp. 13-32. 
Bloom D. E., Cafiero E. T., Jané-Llopis E., Abrahams-Gessel S., Bloom L. R., Fathima S., Feigl A. B., Gaziano T., Mowafi M., Pandya A., Prettner K., Rosenberg L., Seligman B., Stein A. Z. and Weinstein C. (2011) The Global Economic Burden of Noncommunicable Diseases, Geneva, World Economic Forum, $48 \mathrm{p}$.

Chambon Nicolas, Cochet Pierre et Le Goff Gwen (2013) Soigner des migrants précaires en psychiatrie publique, Écarts d'identité, pp. 38-44, [enligne]. URL : https://halshs.archivesouvertes.fr/halshs-00978254

Charlson Fiona J., Diminic Sandra, Lund Crick, Degenhardt Louisa and Whiteford Harvey A. (2014) Mental and Substance Use Disorders in Sub-Saharan Africa: Predictions of Epidemiological Changes and Mental Health Workforce Requirements for the Next 40 Years, PLOS ONE, 9 (10), [online]. URL: https://journals.plos.org/plosone/article?id=10.1371/journal.pone.0110208

Cognet Marguerite, Hoyez Anne-Cécile et Poiret Christian (Coord.) (2012) Expériences de la santé en migration, Revue Européenne des Migrations Internationales, 28 (2), pp. 7-170.

Collignon René (2006) La psychiatrie coloniale française en Algérie et au Sénégal : esquisse d'une historisation comparative, Revue Tiers-Monde, 187, pp. 527-546.

Collignon René (1999) Le traitement de la folie au Sénégal à l'époque coloniale, in Bernault Florence, Enfermement, prisons et châtiments en Afrique du 19e siècle à nos jours, Paris, Khartala, pp. 227-258.

Collignon René, Osouf Patrick et Sylla Omar (1977) Thiaroye ou les avatars d'une institution, Psychopathologie africaine, 13 (1), pp. 81-111.

Collomb Henri (1967) Rencontre de deux systèmes de soins. À propos de thérapeutiques des maladies mentales en Afrique orientale, Social Science \& Medicine, 7 (8), pp. 623-633.

Comaroff Jean and Comaroff John (1987) The madman and the migrant: work and labor in the historical consciousness of a South African people, American Ethnologist, 14 (2), pp. 191-209.

Crenn Chantal, Hassoun Jean-Pierre et Medina F. Xavier (2010) Introduction : repenser et réimaginer l'acte alimentaire en situations de migration, Anthropology of food, 7, [en ligne] consulté le 25/02/2019. URL : https://journals.openedition.org/aof/6672

Devarenne-Megas Hanna (2003) Psychopathologie et insertion sociale des migrants polonais en France, Revue Européenne des Migrations Internationales, 19 (1), pp. 101-124.

Ehrenberg Alain (2000) La fatigue d'être soi. Dépression et société, Paris, Odile Jacob, 409 p.

Faris Robert E. Lee and Dunham H. Warren (1939) Mental Disorders in Urban Areas: an Ecological Study of Schizophrenia and other Psychoses, Chicago, University of Chicago Press.

Fassin Didier (2000a) Les politiques de l'ethnopsychiatrie. La psyché africaine, des colonies africaines aux banlieues parisiennes, L'Homme, 153, pp. 231-250.

Fassin Didier (2000b) Repenser les enjeux de santé autour de l'immigration, Hommes et Migrations, 1225 , pp. 5-12.

Fassin Didier (1999) L'ethnopsychiatrie et ses réseaux : l'influence qui grandit, Genèses, 35, pp. 146-171.

Gómez Martín Carmen (2016) La génération sahraouie de la guerre : des études à Cuba à la migration économique en Espagne, Revue Européenne des Migrations Internationales, 32 (2), pp. 77-94.

Halima Zeroug-Vial, Le Goff Gwen, Benkorichi Malorie et Chambon Nicolas (2012) État des lieux national de la santé mentale des demandeurs d'asile et réfugiés au sein du dispositif national 
d'accueil. Mise en perspective problématique, Réseau Samdarra. Récits et paroles de migrants en quête d'asile. Quels enjeux? Quels effets sur la santé mentale ?, Lyon, pp. 3-5.

Halluin Estelle (d') (2009) La santé mentale des demandeurs d'asile, Hommes et migrations, 1282, pp. 66-75.

Keller Richard C. (2007) Colonial Madness: Psychiatry in French North Africa. Chicago and London, The University of Chicago Press, $320 \mathrm{p}$.

Kilroy-Marac Kathleen (2009) The impossible inheritance: Memory and Postocolonial subjectivity at the Fann Hospital in Dakar, Senegal, Columbia University, NY, Thesis for the degree of Doctor of Philosophy in Graduate School of Arts and Sciences.

Laliberté Danièle (2007) Crises humanitaires, santé des réfugiés et des déplacés : un cadre analytique, Revue Européenne des Migrations Internationales, 23 (3), pp. 85-96.

Ly Mouhamed, Petit Véronique et Pizzolato Giulia (2014) La migration internationale face à la santé mentale au Sénégal : récits, discours et imaginaires, in Cécile Canut et Catherine Mazauric Éds., Les mots de la migration. Mise en récits et en images des migrations transafricaines, Paris, Éditions Le cavalier bleu, pp. 221-239.

Melchior Maria, Chastang Jean-François, Falissard Bruno, Galéra Cédric, Tremblay Richard E., Côté Sylvana and Boivin Michel (2012) Food Insecurity and Children's Mental Health: A Prospective Birth Cohort Study, PLoS ONE, 7 (12), [online]. URL: https://journals.plos.org/ plosone/article?id=10.1371/journal.pone.0052615

Moussy Hugues (2015) Le regard des médecins topographes sur l'Algérie coloniale, Revue Européenne des Migrations Internationales, 31 (3), pp. 231-251.

Muel-Dreyfus Francine (2018) Abdelmalek Sayad : sociologie historique et sociologie clinique de l'émigration/immigration, in Isabelle Coutant et Simeng Wang Dir., Santé mentale et souffrance psychique. Un objet pour les sciences sociales, Paris, CNRS Éditions, pp. 115-117.

Nathan Tobie (2000) Psychothérapie et politique. Les enjeux théoriques, institutionnels et politiques de l'ethnopsychiatrie, Genèses, 38 (1), pp. 136-159.

Ndione Babacar et Lombard Jérôme (2004) Diagnostic des projets de réinsertion économique des migrants de retour : étude de cas au Mali (Bamako, Kayes), Revue Européenne des Migrations Internationales, 20 (1), pp. 7-27.

Ochs Elinor and Capps Lisa (1996) Narrating the self, Annual Review of Anthropology, 25, pp. 19-43.

Ochs Elinor and Sterponi Laura (2003) Analisi delle narrazioni, in Giuseppe Mantovani e Anna Spagnolli Eds., Metodi qualitativi in psicologia, Il Mulino, pp. 131-158.

Ortigues Marie-Claude et Ortigues Edmond (1966) đEdipe africain, Paris, Plon, 321 p.

Patel Vikram, Shekhar Saxena S., Lund Crick, Thornicroft Graham, Baingana Florence and Bolton Paul (2018) The Lancet Commission on global mental health and sustainable development, The Lancet, $46 \mathrm{p}$.

Pestre Élise (2010) La vie psychique des réfugiés, Paris, Payot et Rivages, 318 p.

Pryor Laura, Strandberg-Larsen Katrine, Nybo Andersen Anne-Marie, Rod Naja Hulvej and Melchior Maria (2019) Trajectories of family poverty and children's mental health: Results from the Danish National Birth Cohort, Social Science \& Medicine, 220, pp. 371-378.

Rechtman Richard (2018a) Aux origines de l'ethnopsychiatrie, in Isabelle Coutant et Simeng Wang Dir., Santé mentale et souffrance psychique. Un objet pour les sciences sociales, Paris, CNRS Éditions, pp. 73-97. 
Rechtman Richard (2018b) Postface, in Isabelle Coutant et Simeng Wang Dir., Santé mentale et souffrance psychique. Un objet pour les sciences sociales, Paris, CNRS Éditions, pp. 401-405.

Rechtman Richard (2000) De la psychiatrie des migrants au culturalisme des ethnopsychiatres, Hommes et Migrations, 1225, pp. 46-61.

Rechtman Richard et Welsh Geneviève (1993) Approche transculturelle des patients non francophones originaires du Sud-est asiatique dans le dispositif psychiatrique du XIIIe arrondissement de Paris, Santé mentale au Québec, 18 (1), pp. 143-161.

Ricœur Paul (1987) Soi-même comme un autre, Paris, Édition du Seuil, 448 p.

Roze Mathilde, Vandentorren Stéphanie, Vuillermoz Cécile, Chauvin Pierre and Melchior Maria (2016) Emotional and behavioral difficulties in children growing up homeless in Paris. Results of the ENFAMS survey, European Psychiatry, 38, pp. 51-60.

Saglio-Yatzimirsky Marie-Caroline (2018) La voix de ceux qui crient. Rencontre avec des demandeurs d'asile, Paris, Alban Michel, 318 p.

Saglio-Yatzimirsky Marie-Caroline (2015) Kalapani : le trauma de la traversée dans la migration des demandeurs d'asile tamouls du Sri Lanka, Migrations Société, 161.

Sayad Abdelmalek (1999) La double absence. Des illusions de l'émigré aux souffrances de l'immigré, Paris, Le Seuil, 437 p.

Storper-Perez Danielle (1974) La folie colonisée, Paris, François Maspéro, 156 p.

Streiff-Fénart Jocelyne et Poutignat Philippe (2014) Vivre sur, vivre de la frontière : l'après transit en Mauritanie et au Mali, Revue Européenne des Migrations Internationales, 30 (2), pp. 91-111.

Sylla Omar et Mbaye Mor (1990-1991) Psychopathologie et migration : un cas de « wootal ", Psychopathologie africaine, 23 (3), pp. 353-363.

Thomas William I. et Znaniecki Florian (1998 [1919]) Le paysan polonais en Europe et en Amérique : récit de vie d'un migrant, Paris, Nathan, $446 \mathrm{p}$.

Viggo Daniel, Thornicroft Graham and Atun Rifat (2016) Estimating the true global burden of mental illness, The Lancet Psychiatry, 3, pp. 171-178.

Wang Simeng (2018) Étudier les souffrances des migrants : à partir du cas des Chinois en France, in Isabelle Coutant et Simeng Wang Dir., Santé mentale et souffrance psychique. Un objet pour les sciences sociales, CNRS Éditions, pp. 325-344.

Wang Simeng (2017) Illusions et souffrances. Les migrants chinois à Paris. Paris, Éditions rue d'Ulm, $220 \mathrm{p}$.

Wang Simeng (2016a) Souffrances psychiques et mobilité sociale ascendante : le cas des adolescents français d'origine chinoise à Paris, Hommes \& Migrations, 1314, pp. 11-18.

Wang Simeng (2016b) Entre stratégie et moralité. Des migrants chinois en situation irrégulière face à la « clause de maladie », Politix, 114, pp. 205-227.

Wang Simeng (2016c) « Aidez-nous à comprendre vos Chinois ! Conditions de possibilités de la légitimation du sociologue en milieu psychiatrique, Genèses, 105, pp. 141-156.

Wang Simeng (2015) Des « soucis matrimoniaux » dans le contexte transnational : le cas des migrant·e·s chinois·es qualifiée's à Paris, Migrations Société, 27 (157), pp. 149-166. 
Wang Simeng (2014) «Enfant abandonné en Chine puis domestique en France. Que suis-je pour eux ? ! Obligations familiales à rebours des enfants migrants d'origine chinoise à Paris, Enfances, Familles, Générations, 20, pp. 21-44.

Wang Simeng (2013a) Analyses sociologiques des pratiques de l'interprétariat-médiation en pédopsychiatrie : l'exemple des familles d'origine chinoise à Paris, Enfances \& Psy, 56, pp. 136-146.

Wang Simeng (2013b) « Handicapé ? C'est insulter ma descendance et aussi mes ancêtres ! ». Négociations autour de l'inscription de l'enfant d'origine chinoise à la MDPH, Terrains \& travaux, 23, pp. 77-92.

Wang Simeng (2012) «Une vie qui est ailleurs » : une sociologie des troubles mentaux à travers le parcours d'un adolescent d'origine chinoise à Paris, Lien social et politiques, 67, pp. 233-248.

\section{NOTES}

1. Gourion David (2017) Terrorisme: «les psychiatres n'ont pas vocation à collaborer avec le ministère de l'intérieur ", Le Monde, 21/08/2017, [online]. URL: https://www.lemonde.fr/idees/ article/2017/08/21/les-psychiatres-n-ont-pas-vocation-a-collaborer-avec-le-ministere-de-1interieur_5174728_3232.html

2. Examples of the most recent dossiers illustrating this perspective include the following: 2017 , 33 (2); 2017, 33 (4); 2016, 32 (2); 2014, 30 (1).

\section{INDEX}

Palabras claves: salud mental, trayectoria migratoria, relación terapéutica, sufrimiento mental, flujos transnacionales de salud, pluralismo médico, políticas públicas

Mots-clés: santé mentale, trajectoire migratoire, relation thérapeutique, souffrance psychique, circulations transnationales en santé, pluralisme médical, politiques publiques

Keywords: mental health, migratory trajectory, therapeutic relationship, mental suffering, transnational circulations in health, medical pluralism, public policies

\section{AUTHORS}

\section{VÉRONIQUE PETIT}

Demographer, Professor, CEPED, Paris Descartes University - IRD, 45 rue des Saints Pères 75006 Paris ; veronique.petit@parisdescartes.fr

\section{SIMENG WANG}

Sociologist, Researcher at CNRS, CERMES3 (CNRS-EHESS-INSERM- Paris Descartes University), 7 rue Guy Môquet, BP 8, 94801 Villejuif Cedex; simeng.wang@cnrs.fr 